\title{
Land Reform in the Era of Global Warming-Can Land Reforms Help Agriculture Be Climate-Smart?
}

\author{
Alexis Rampa *, Yiorgos Gadanakis (D) and Gillian Rose \\ School of Agriculture, Policy and Development, University of Reading, Earley Gate, off Whiteknights Road, \\ Reading RG6 6EU, UK; g.gadanakis@reading.ac.uk (Y.G.); g.rose@reading.ac.uk (G.R.) \\ * Correspondence: alexis.rampa@pgr.reading.ac.uk
}

Received: 26 October 2020; Accepted: 21 November 2020; Published: 24 November 2020

\begin{abstract}
In an era of global warming, long-standing challenges for rural populations, including land inequality, poverty and food insecurity, risk being exacerbated by the effects of climate change. Innovative and effective approaches, such as Climate Smart Agriculture (CSA), are required to alleviate these environmental pressures without hampering efficiency. In countries with unequal distribution of land, where issues of access to and use of land rank high on the policy agenda, policymakers are confronted with the challenge of implementing interventions such as land reforms, whilst endeavouring to ensure that sustainable agriculture approaches be adopted by farm-households. The aim of this study is to investigate how land reforms can provide an opportunity for policymakers, particularly in lower-income countries, to enhance not only equity and efficiency but also environmental sustainability. In particular, this study builds on an extensive review of the theoretical and empirical literature and employs a conceptual framework analysis method to develop and describe a framework that explores how land reforms can be associated with the CSA approach. The resultant "Climate Smart Land Reform" (CSLR) framework contains four driving pillars, namely land redistribution, tenure reform, rural advisory services and markets and infrastructure. The framework disentangles relevant channels through which land reform, via its four pillars, can foster CSA adoption and thus contribute to the attainment of sustainable increases in agricultural productivity, climate change adaptation and climate change mitigation. The framework also includes relevant channels through which more 'traditional' objectives of land reformers, including economic, social and political objectives, can be achieved. In turn, the (partial) attainment of such objectives would lead to improvements in agroecological and socioeconomic conditions of rural areas and populations. These improvements are considered within the framework as the 'ultimate' objective of land reformers. The CSLR framework represents an innovative way of conceptualising how land reforms can generate beneficial effects not only in terms of equity and efficiency but also of environmental sustainability.
\end{abstract}

Keywords: climate smart agriculture; land reform; land redistribution; land tenure; sustainable agriculture; sustainable development; rural development; climate change adaptation; climate change mitigation

\section{Introduction}

Enhancing food security in the context of an increasing population and global warming requires the implementation of innovative and effective approaches across food systems. Climate Smart Agriculture (CSA) is a sustainable agriculture approach that includes climate change in two of its three objectives-sustainable increases in agricultural productivity, climate change adaptation and climate change mitigation [1,2]. Institutions that have pioneered CSA include the Food and Agriculture Organization of the United Nations (FAO), who first introduced the CSA concept in a 2009 report and 
then more formally in 2010 [3,4], the Consultative Group for International Agricultural Research [5,6] and the World Bank Group [7-9]—all members of the Global Alliance for Climate Smart Agriculture (GACSA). CSA should not be prescribed as a specific set of agricultural practices and technologies universally adoptable. Rather, it should be understood as a holistic approach that can include both traditional and modern agricultural practices and technologies, insofar as these contribute positively (or at least non-negatively) to the attainment of the three CSA objectives [1].

The existence of a wide range of agricultural practices with "climate-smart" potential and the rising popularity of the approach have led to a growing literature on CSA and numerous studies have analysed drivers and barriers to CSA adoption (see, for instance, [10-14]). Unsurprisingly, these studies reveal that there exists a wide range of factors determining or limiting CSA adoption by farmers. This is due to the existence of a large heterogeneity between the different contexts studied, but also between the specific CSA practices analysed within each study.

In order to implement successful CSA strategies, stakeholders at both the farm level and the wider economic and political environment need to make decisions on the allocation and use of resources, including finite natural resources such as land [15]. At the policy level, this can translate into interventions such as land reforms that have the potential to advance, on the one hand, a socially efficient allocation of land and, on the other hand, an enabling environment for scaling CSA adoption. However, there is no existing framework that can be utilised to explore the specific linkages between land reforms and CSA adoption. This study intends to fill this gap by investigating the potential channels connecting land reforms to CSA and does so via the construction of a conceptual framework. The overarching aim of this study is to investigate how land reforms can provide an opportunity for policymakers, particularly in lower-income countries, to enhance not only equity and efficiency but also environmental sustainability. The general research questions that this paper addresses are as follows:

(1) Can land reforms be considered a conducive environment to foster CSA adoption?

(2) What are the main channels through which land reforms may affect CSA adoption and the realisation of land reformers' objectives?

Two premises are important at this stage. The first concerns the definition of land reform and the second narrows down the scope of the definition within this paper. Multiple definitions of land reform have been employed in the literature. These range from narrower definitions, which focus mostly on land redistribution [16-19], to definitions which broaden the scope of land reforms to include complementary measures in support of land reform beneficiaries [20-23]. In the context of this paper, a relatively broad definition of land reform is used: "Land reform is the generic term for modifications in the legal and institutional framework governing land policy" [24] (p. 69). ${ }^{1}$ Moreover, the focus is placed on agricultural land reforms, omitting reforms directly affecting urban tenures and urban land use.

Because of the specificity of each country context, modern land reforms have been developed and implemented in a variety of forms and for a variety of reasons. ${ }^{2}$ Land reforms include interventions related to two broad categories. The first category considers changes in the tenure structure and includes both land redistribution (i.e., the reallocation of land, therefore affecting directly land concentration) and land tenure reforms (i.e., "changes to the rules of tenure" [25] (p. 47)). These represent the first two pillars that drive the conceptual framework introduced in this paper. Both land redistribution and tenure reforms can be undertaken in a variety of forms and indeed there are circumstances where they coexist. Land redistribution programmes can be State-led, market-led or hybrids of the two [26]. In addition, land redistributions can have a multitude of different specific characteristics and

1 Land policy refers to "the set of intentions embodied in various policy instruments that are adopted by the state to organise land tenure and land use" [24] (p. 69).

2 In addition to country contexts, evolutions in external pressure trends have also played a role in influencing the types or forms of land reforms in different countries. Examples of these pressures are the Alliance for Progress (AfP) set by the United States (US) Government in 1961 or the World Bank's influential role in prioritising land titling programmes in numerous developing countries in the last decades of the twentieth century and in supporting market-led land reforms. 
triggering factors. Tenure reforms can range from tenancy reduction or rebalancing laws, to tenancy registration, legal recognition of customary tenure rights, patrialisation, collectivization, etc. (see, for instance, $[18,27])$. In some circumstances land redistribution programmes have been complemented with tenure reforms aimed at enhancing tenure security (e.g., in South Africa), in other circumstances tenure reforms have been employed as a means to transfer land (e.g., the land to the tiller reforms of East Asia; the patrialisation schemes occurring after decolonisation). The second broad category relates to interventions affecting the support services available to rural populations, and in particular to land reform beneficiaries. These include interventions linked to Markets and Infrastructure (MaI) and to Rural Advisory Services (RAS). Although such services "may or may not be extended or improved with or without land reform" [28] (p. 12), there is ample recognition in the literature of the crucial importance of these support services for the attainment of the objectives of land reformers [27,29-32]. $\mathrm{MaI}$ and RAS are thus included in the framework as the third and fourth pillars driving the framework.

The objectives of land reformers represent the second main component of the framework. In general terms, the 'traditional' objectives of land reformers are rooted in economic, social and political grounds $[28,33-35]$. These include objectives such as the reduction of inequality and poverty, enhancing agricultural productivity and output growth, economic growth, avoiding conflicts, increased employment, gender equality, freedom and stability (both economic and political). Occasionally, references can include environmental considerations and environmental sustainability as an additional objective of land reformers [36-39]. In the conceptual framework advanced in this study, both 'traditional' objectives and environmental objectives are included. The environmental objectives are represented by the three CSA objectives-sustainable increases in agricultural productivity, climate change adaptation and climate change mitigation. In the remainder of the paper, we therefore refer to it as the "Climate Smart Land Reform (CSLR)" framework.

The CSLR framework introduced and analysed in this paper represents an innovative way for policymakers to integrate the CSA objectives in the (re)design phase of land reform, alongside the more 'traditional' objectives, and to consider appropriate channels through which these objectives can be attained. Moreover, it presumes that the (partial) attainment of these objectives generates positive effects on what is considered to be the 'ultimate' objective of land reformers within the framework: improved agroecological and socioeconomic conditions of rural areas and populations.

This paper is structured as follows. The Section 2 provides a brief background on the four pillars driving the CSLR framework. The Section 3 focuses on the first two pillars of the framework, namely land redistribution and tenure reform, and explores the main channels through which these can affect CSA adoption and the attainment of 'intermediate' and 'ultimate' objectives of land reformers. The Section 4 describes such channels for the latter two pillars of the framework, MaI and RAS (i.e., the support services available to land reform beneficiaries). The Section 5 concludes, providing a brief discussion on the potential uses of the framework.

\section{Overview of The Four Pillars Driving the CSLR Framework}

The CSLR framework introduced in this paper is illustrated in Figure 1. The framework has been elaborated by following the various phases of the conceptual framework analysis [40], a qualitative research method employed widely across a multitude of research fields (see, for instance, applications of the method by [41-45]). The analysis involved undertaking an extensive multidisciplinary review of the theoretical and empirical literature surrounding the subjects of land reform and CSA. This enabled us to identify, name and categorise the various key concepts, and subsequently to integrate and synthesise these concepts within a framework. The procedure was further enriched by the feedback received during the validation phase of the analysis. ${ }^{3}$ This iterative process resulted in the CSLR

3 For a detailed explanation of the conceptual framework analysis, including a description of the different phases composing the methodology see [40] (pp. 53-54). 
conceptual framework depicted in Figure 1, which is driven by the four pillars of land redistribution, tenure reform, Markets and Infrastructure (MaI) and Rural Advisory Services (RAS). Although the framework suggests that land reforms which combine interventions on the four pillars can enhance the likelihood of CSA adoption and generate exponential benefits on the livelihoods of rural populations, it also recognises that in specific country contexts it might not be feasible (or in particular cases necessary) to act on all four pillars simultaneously. This may be due to a multitude of factors, including pre-reform tenure arrangements, status of markets and infrastructure, demands and expectations of potential land reform beneficiaries, budgetary constraints, among others. In contexts where, for instance, farm operation is already undertaken by peasant-like farmers (via fixed rent or sharecropping types of tenancy arrangements), there may be less or no need for direct land redistribution: land to the tiller types of tenure reforms may be more appropriate. ${ }^{4}$ Instead, where tenure types imply that farm operation is undertaken by wealthier farmers (via the hiring of labour) then redistributive types of land reform may be more relevant [46]. In other instances where rural infrastructure may already be deemed to be satisfactory, financial efforts to improve these may not be an immediate priority and could be sequenced out appropriately.

This implies that the framework does not prescribe the don't do anything till you can do everything doctrine. ${ }^{5}$ Rather, it considers that land reform which combines actions related to the four pillars can enhance the likelihood of CSA adoption and generate exponential benefits for the livelihoods of rural populations, but that interventions on individual pillars can nonetheless be advisable. Moreover, different demands from land reform beneficiaries will emerge with respect to the individual pillars, based on a multitude of factors including the pre-reform tenure arrangements. The framework acknowledges that a partial land reform is better than no land reform and that the specific pre-land reform context is crucially important in determining the relevant set(s) of intervention(s) to be undertaken on each pillar.

It is also important to note that the four pillars upon which the framework is built are strongly interconnected with the overall land management activities present at the country level. These include the underlying broader institutional arrangements governing land policy, the land information infrastructure developed within a country and the land administration systems [47]. Although not described in this paper, these play a crucial role in the efficacy of a land reform.

4 Such reforms consist essentially in transforming farm operation in farm ownership. Typical examples of successful land to the tiller types of reform are those that occurred after the end of the Second World War in Eastern Asia (Japan, Taiwan, South Korea).

5 This doctrine, which argues that only comprehensive interventions can be effective and that little, if any, benefit can be obtained without concurrent action on all facets, may put at risk the realisation of any land reform actions $[18,29]$. 


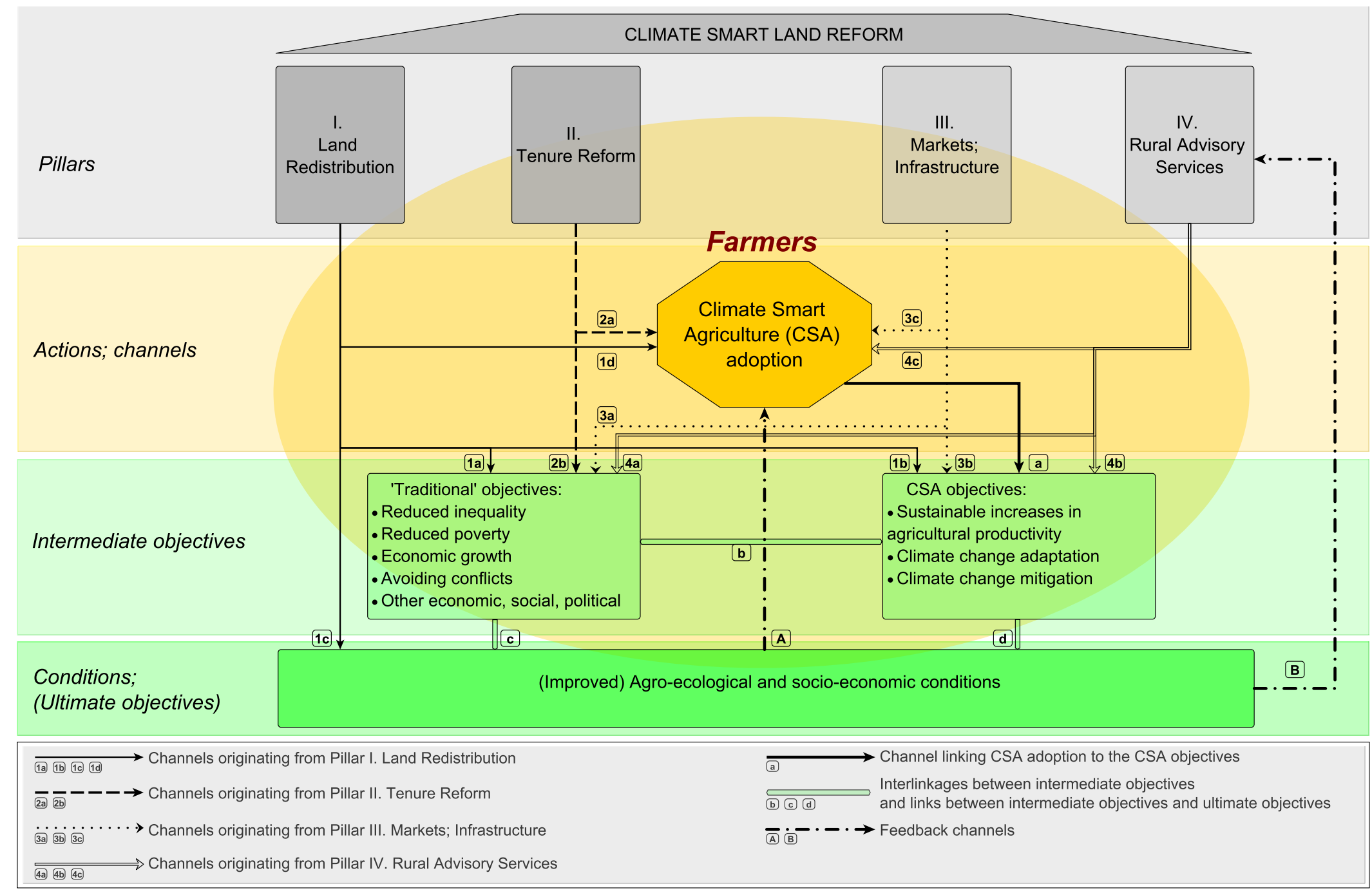

Figure 1. Climate Smart Land Reform framework (Source: Authors). 


\section{Changes in the Tenure Structure: Land Redistribution and Tenure Reform}

\subsection{Pillar I: Land Redistribution}

The first of the four pillars shown in Figure 1 is land redistribution and involves the passage of an asset (the land) from individuals or groups of individuals (the "land losers") to other individuals (the "land gainers"). Traditionally, land redistribution programmes are undertaken by the State as main actor (so-called State-led redistributions), who either centrally or via devolved administration (e.g., regional, provincial, communal governments) sets, in a more or less participatory manner, the grounding rules for the redistribution (e.g., ceiling on the amount of land that an individual can possess; whether a compensation shall be paid to the land losers, by whom, when and in what amount; which geographic areas are to be prioritised, etc.). The State also sets the procedures for the implementation of the programme (e.g., the requirements and processes for individuals to be included among the land gainers; the processes for, and the timing of, the possession of the land from the land losers and the subsequent distribution to the land gainers) [18]. These State-led programmes characterised most of the land redistributions that occurred before the 1990s (e.g., Mexico, Cuba, Chile, Peru, Iraq, Iran, Egypt, China, Vietnam, etc.). More recently, alternative forms of land redistribution emerged, which altered the role of the State to that of market facilitator (so-called market-led or market assisted redistributions). This occurred, particularly since the 1990s, in countries such as Colombia, Brazil, South Africa and Malawi [48-50]. There also exists a hybrid "joint state/market land redistributive policy" [26] (p. 31), whereby the redistribution can occur both via willing-seller and willing-buyer market processes and via expropriation and redistribution from the State (e.g., in the Philippines). Land redistributions can also be characterised by their main triggering factor(s). Social revolutions have, for instance, played a role in creating the basis for land reform in numerous countries (e.g., Mexico, Cuba, Nicaragua, Algeria, Iran, South Africa), as have decolonisation processes (e.g., Kenya, Zimbabwe), external pressures (e.g., AfP in Latin America), and peoples' movements (e.g., Movimento dos Trabalhadores Rurais Sem Terra in Brazil). The CSLR framework outlines three broad effects that can result from land redistributions.

First, land redistribution is expected to contribute to the attainment of 'traditional' objectives of land reformers, which consist of a reduction in inequality and in poverty, increase in economic growth, avoidance of conflicts, as well as other economic, social and political goals (e.g., employment creation, political stability, enhancing peasant and peasant-like farmers' freedom). These complex relations are represented by the arrow " $1 \mathrm{a}$ " linking the land redistribution pillar to the 'traditional' objectives box in Figure 1. By reallocating land from large landholders to small landowners or to the landless, land redistribution interventions generate a decrease in within-country inequality. This is often a 'traditional' objective of land reformers per se [18,19,51]. Reduced inequality, in turn, can be a contributor to other 'traditional' objectives, including reducing poverty (via increased land assets to the rural poor) and increasing political stability and economic growth [52-54]. Furthermore, land redistribution is expected to generate positive effects on rural employment, both on-farm and off-farm. On-farm employment is created by increased labour demand of land redistribution beneficiaries whose small farms employ more labour per hectare compared to larger farms [18,54]. Off-farm employment is generated via the increase in demand for labour involved in input production and output processing, distribution and sale used by land redistribution beneficiaries, as well as by the increased demand for consumption goods and services at the community or local level. These positive pressures on rural employment would also translate into economic growth, ${ }^{6}$ political stability and reduction of poverty. In terms of poverty reduction, one caveat should be mentioned. Although land redistribution can have beneficial effects on poverty overall, there may be circumstances where distress sales of

6 "Best-guess generalizations [of the multiplier effects stemming from agricultural to rural non-farm income] probably lie in the range of 1.6 to 1.8 in Asia and 1.3 to 1.5 in Africa and Latin America" [55] (p. 167). Moreover, "indirect income gains at the national level exceed those for rural regions by 50 to 150 percent, increasing indirect income gains [above those generated in the rural non-farm economy] by 30 to 90 cents for each initial dollar of agricultural income growth" [55] (p. 159). 
land may occur (from very poor, vulnerable beneficiary farmers to wealthier farmers) thus partially cancelling out the beneficial effects. This risk can be mitigated by correcting land market distortions, by enacting and enforcing land ownership floors and ceilings legislation and by temporarily prohibiting the resale of land or taxing (moderately) the sale of reformed land to deter disadvantageous resales of land $[18,56,57]$. Land redistribution is also considered to be a means to avoid conflicts $[18,19,33]$, which is often a precondition for positive social, economic and political developments. Moreover, land redistribution has the potential to enhance "freedom of the person of the peasant, freedom of the land" [28] (p. 182) and, more generally, to expand human freedom (in the spirit of Sen [58]). Indeed, these positive effects would lead to an improvement in the socio-economic conditions of farmers and rural populations.

Second, land redistribution interventions in lower-income country settings may enhance agricultural productivity, which appears in Figure 1 under the CSA objectives box, hence the arrow " $1 b$ " linking the land redistribution pillar at the top of the figure to the CSA objectives box. ${ }^{7}$ In labour-abundant and capital-scarce contexts, where market imperfections are present, as is the case in most lower-income countries, a stylised fact emerges: the presence of an Inverse Relationship (IR) between farm size and land productivity. Much as some authors have questioned the existence of such an IR $[59,60]$, and indeed there may be, in particular circumstances, exceptions to the rule, ${ }^{8}$ the IR has been found in lower-income country settings independently of the agrarian structure, institutional environments and agroecological conditions. From Latin American and Caribbean countries as diverse as Brazil, Colombia, the Dominican Republic or Barbados, to significantly different Sub-Saharan African countries, such as Madagascar, Kenya and South Africa, and in a number of Asian countries such as Bangladesh, the Philippines, Pakistan and India, the IR has been regularly found [38,57,61-63]. In addition, where appropriate methods were used, the IR has been found to be robust to a number of objections raised by authors who suggested that it was induced by biases such as measurement error, sample selection or omitted variables $[64,65]$. The effect of land redistribution on efficiency (agricultural productivity) can also result from positive effects on nutrition: "Under circumstances of extreme poverty and landlessness redistribution of land can also enhance efficiency by improving the nutritional wellbeing and thus the productive capacity of the population" [57] (p. 2731).

Third, land redistribution interventions can enhance the likelihood of CSA adoption. This effect may occur through the combination of two automatic channels. The first channel relates to the link between the land redistribution pillar and the agroecological conditions box at the bottom of Figure 1 (arrow "1 1 "). In fact, the redistribution of land will define the agroecological conditions under which farmers will be operating their newly obtained land. Land reform beneficiary farmers will obtain land with different agroecological characteristics depending, for instance, on the specific location of the attributed land. In turn, these agroecological conditions will influence the farmer's land use, including whether or not the farmer will be prone to adopt particular types of CSA practices. ${ }^{9}$ In this regard, empirical literature is consistent with the intuition that agroecological conditions affect adoption of agricultural practices with climate-smart potential, both quantitatively (i.e., the amount of practices adopted and the intensity of adoption) and qualitatively (i.e., the types of practices adopted) [11,66-73].

7 A caveat here is that the agricultural productivity gains derived from land redistribution may not necessarily be sustainable. This factor provides an additional justification for the inclusion of the adoption of CSA practices within this framework as a means to attain the objective of sustainable increases in agricultural productivity.

8 [61], for instance, finds an IR for 12 of the 15 countries studied and indicates that the results from the three countries for which no statistically significant relationship was found (Peru, Bangladesh and Thailand) were "probably due to the limited number of observations [ . . . ] scanty information [ . . and] limited farm differentiation" [61] (p. 524).

9 The propensity of the farmer to adopt particular CSA practice(s) will of course also be dependent upon the farmer's information and knowledge of the CSA practice(s). Moreover, beyond the farmer's intention to adopt particular CSA practice(s), there may exist barriers that limit the possibility for the farmer's intention to translate into actual implementation (e.g. lack of tenure security, poor access to markets, infrastructure and rural advisory services). These aspects further substantiate this paper's thesis that land reforms which combine interventions on the various CSLR pillars can substantially enhance the likelihood of CSA adoption. 
Along with the agroecological conditions at the farm level, there exists a second automatic channel linking land redistribution to CSA adoption which can be visualised in Figure 1 by arrow " $1 \mathrm{~d}$ " linking the land redistribution pillar to the CSA adoption octagon at the centre of the figure. This channel can be traced back to one of the root causes of the IR described above: the existence of lower labour transaction costs for smaller farms compared to larger ones. This creates an incentive for smaller farms to invest in labour intensive agricultural practices [18,36,61]. In turn, labour intensive agricultural practices, such as soil and water conservation practices (e.g., building and maintaining contour ditches, live and/or dead barriers, terraces, zaï pits), vegetable growing (in place of, or in addition to, cereals) and more intensive use of by-products (e.g., zacate—for live barriers, for feeding livestock and for sale—green and animal manure) are all practices that have the potential to be considered as climate-smart since they can produce beneficial effects on the three CSA objectives [1]. Therefore, redistributing land from farmers with large amounts of land, who experience relatively high labour transaction costs, to the landless or to farmers owning very small land parcels and thus with lower labour transaction costs, can generate positive effects in terms of CSA adoption. In studies that have analysed the determinants of practices with climate-smart potential, there is evidence that farm size affects adoption of such practices $[68,71,74-77]$. This would imply that the IR between farm size and land productivity described above could also apply to farm size and CSA adoption. ${ }^{10}$

In summary, despite the large variation in the triggering factors and characteristics of land redistributions, theory and empirical evidence suggest that land redistributions can produce a wide range of beneficial effects on the livelihoods of rural populations. These include generating social, economic and political improvements (i.e., achieving the 'traditional' objectives of land reformers), as well as environmental improvements via farmers' adoption of CSA, thus contributing to the attainment of CSA objectives (arrow "a" in Figure 1). Indeed, these categories of objectives are interconnected (hence the double-sided arrow " $\mathrm{b}$ " in the figure). ${ }^{11}$

These effects uncover the first of the two iterative elements present in the CSLR framework. ${ }^{12}$ The combination of beneficial effects of land redistribution on both categories of 'intermediate' objectives (i.e., 'traditional' and CSA objectives) would result in improved agroecological and socio-economic conditions of the farm and farm-household (arrows " $c$ " and " $d$ " in Figure 1, respectively). In turn, these new agroecological and socioeconomic conditions would influence the type of CSA practice(s) most appropriate to the farm and the propensity of farmers to adopt CSA practices/technologies. This is represented by arrow " $\mathrm{A}$ ", feeding back from the agroecological and socioeconomic conditions box at the bottom of Figure 1 to the CSA adoption octagon at the centre of the figure. A farmer in a particular socioeconomic state, experiencing particular agroecological conditions, may be more or less prone to adopt specific CSA practices based on how these conditions are affecting (or have the potential to affect) the farm-household's food security and livelihoods. Thereafter, the adoption of CSA (and its consequent effect on the CSA objectives) would lead to a further improvement in the agroecological and socioeconomic conditions of the farm and of the farm-household giving rise to a potentially virtuous cycle.

10 It should be noted here, however, that the empirical evidence in this regard is not conclusive. There exist studies that have found a positive relationship between farm size and CSA adoption [11,12,78]. Inconclusive results on the relationship between farm size and agricultural technology adoption have also been highlighted in earlier studies [79]. However, in our view, this is likely to be due to the fact that most studies of adoption of practices with climate-smart potential focus on smallholder farmers only and to the large variation in the specific agricultural practices analysed. This is confirmed by studies that have analysed multiple practices with climate-smart potential and found positive effects of land size on adoption of certain practices and negative effects on adoption of other ones [74,80-82]. Interestingly, studies investigating the effect of CSA adoption on productivity have also confirmed the presence of the IR between farm size and land productivity $[11,68,74,83]$.

11 Sustainable increases in agricultural productivity, for instance, would translate in agricultural output growth and in economic growth.

12 The second is described at the end of Section 4 below. 


\subsection{Pillar II: Tenure Reform}

The second pillar presented in the CSLR framework is tenure reform. Prior to describing the channels linking tenure reform to CSA adoption and to the 'intermediate' and 'ultimate' objectives of land reformers summarised in Figure 1, an introduction to some of the fundamental concepts underlying tenure reform is provided in the following two paragraphs.

Land tenure corresponds to "the relationship, whether legally or customarily defined, among people, as individuals or groups, with respect to land and associated natural resources (water, trees, minerals, wildlife, etc.). Rules of tenure define how property rights in land are to be allocated within societies." [25] (p. 46). From this definition, two further clarifications should be made. First, given the prominence of property rights in this definition, it is important to understand and distinguish between different categories of property rights to land, which can be pooled under the bundle of rights metaphor. ${ }^{13}$ Rights of control (or of management) correspond to the possibility of deciding what activities shall or shall not be undertaken on the land as well as to decide who can or cannot access and use the land. Use rights (or rights of enjoyment) relate to the possibility to concretely undertake the given range of activities on the land. Transfer rights, in turn, determine the possibility to sell, lease, convey or mortgage the land, thereby offering the possibility to reassign use and/or control rights. The existence of these different categories implies that there may be, at any given moment in time, multiple actors with different rights to the same land. ${ }^{14}$ The second clarification relates to the different types of land tenure that can be present within a given country. In general terms, it is possible to categorise these under four different types, namely nationalised tenure, freehold tenure, leasehold tenure, and customary tenure [89]. ${ }^{15}$ In nationalised (or State) land tenure systems, the State has the rights to the land and can decide to allocate (partial) transfer rights as well as control and use rights to communities or individuals. In freehold (or private) tenure, an individual or a group of individuals is provided with full transfer, control and use rights. In leasehold tenure, an individual or a group of individuals has been transferred, for predetermined periods, use and/or control rights to the land, and in rare circumstances also partial transfer rights (e.g., the rights to sub-lease the land). Finally, in customary tenure, indigenous communities have traditional rights to the land and can allocate, according to customary norms, land use rights to individuals or groups. It is worth noting that although customary tenure rights were once considered to be informal rights, there are now a number of countries across the globe (e.g., Armenia, Bolivia, China, Costa Rica, Dominica, Fiji, Guyana, Malaysia, Mozambique, Papua New Guinea, Peru, South Africa, South Sudan, Tanzania, Uganda, etc.) where customary rights are recognised by statutory legislation and can thus be considered in full effect as formal rights [90].

Against this background, land tenure reform, i.e., the "changes to the rules of tenure" [25] (p. 47), can involve very complex and heterogenous processes, but can often be undertaken to enhance the land rights of populations and increase tenure security [29]. Tenure security can be defined as "the certainty that a person's rights to land will be protected" [25] (p. 48). However, and consistent with the definition of tenure reform indicated above, the definition of tenure security can be extended to refer not only to individuals, but also to groups of individuals and not only to land per se but more generally to natural resources. It could therefore be read as the certainty that a person or a group's rights to land and associated natural resources will be protected. The importance of communities for tenure security is recognised in [25]. However, in that volume communities are listed as one of the "sources of [a person's tenure] security" [25] (p. 19). We argue that, beyond representing a source of tenure security for its members, communities/groups should also be a subject of tenure security recognised by other sources

13 See, for instance, [84,85] for information on the origin of the metaphor in property law.

14 Indeed, there may be more detailed categories, entailing that a more disaggregated list of sticks compose the bundle of rights (see, for instance, [25,86] for a subject-specific categorisation; [87] for a disaggregation of two types of rights, namely use rights and transfer rights; [88]).

15 It often occurs that several tenure types are present within the same country. 
(such as local, regional, central governmental and legislative institutions). Amongst the prominent tenure reforms, tenancy reducing reforms (including land to the tiller reforms), tenancy rebalancing reforms and land formalisation reforms (including land registration and land titling) all have the potential to increase tenure security. In practice, however, this is not always the case. Whilst tenancy reducing reforms, for example, have had beneficial effects including increasing tenure security by transforming tenancy into ownership in countries such as Japan, Taiwan and South Korea, less positive results (and even increases in tenure insecurity resulting in several cases in forced evictions as a means by the landowner to prevent facing the effects of the reform) have been reported for tenancy reducing or rebalancing reforms in other parts of Asia [88] and in Latin America [34,91]. Similarly, it is now recognised in the literature that land registration and land titling programmes do not automatically confer tenure security to participating farmers in all contexts [17,30,92-94].

Tenure reforms, when effective in enhancing tenure security, can engender a number of positive effects that are likely to stimulate CSA adoption and thus the attainment of the three CSA objectives, as well as the attainment of the 'traditional' objectives of land reformers (Figure 1). These effects can be grouped under six categories, namely the collateralisation effect, the assurance effect, the gains from trade effect, the outside investment effect, the community tenure effect and the political stability effect. [95] and [87] describe the first three effects, particularly in the context of land registration and titling; [96] adds to these the outside investment effect and the community tenure effect, providing a detailed analysis of how these five tenure security effects can affect CSA adoption; [33] also points out the importance of the political stability effect.

The collateralisation effect implies that tenure security is one of the preconditions for money-constrained farmers to access credit and thus to undertake long-term land-related investments, including adoption of agricultural practices with climate-smart potential. Farmers with tenure security can use land as collateral when approaching a lending institution, provided that the information relating to this secure tenure is easily accessible to the lender. Hence, the relevance of this effect, particularly for land registration types of interventions and the importance within these of establishing a reliable land registry (and/or ensuring that a reliable land registry is in place), which would allow the lender to easily access the required information. By mitigating the moral hazard and adverse selection problems, and the associated transaction costs, land registration (and the presumed tenure security that would accompany it) can transform the land asset from a state of dead capital to one of live capital $[97,98]$. However, empirical evidence on this effect indicates that the hypothesised automatic link between tenure reform and credit provision does not always occur $[99,100]$. This is due to several possible factors. First, a key aspect related to this effect is that it mostly applies to land formalisation interventions, which can be rendered ineffective under a number of circumstances (for a description of these see, for instance, [92,101]). Second, the availability of land as collateral can be insufficient for lending institutions to provide the loan. This is due to aspects such as the presence of covariance risk in rural settings (and possibly also of collateral-specific risk), the costs of collateral registration and of foreclosure, measured against the often relatively small loans demanded by farmers [92,94,102], but also to the fact that a collateral is only one of the numerous requirements sought by formal lending institutions when considering the issuance of a loan [103]. Moreover, there may also be a risk-rationing effect occurring on the demand side, which may limit the amount of credit demanded by risk-averse farmers [92].

The assurance effect is more psychological in nature compared to the collateralisation effect. It implies that farmers with a (perceived) secure tenure will have an incentive to undertake long-term land-related investments, including the adoption of practices with climate-smart potential, since they are sufficiently confident that they (and their descendants) will reap the benefits associated with these investments. In other words, if farmers are assured that the rights to their land are protected, they will maintain it in such a way that the farm-households can benefit from it in the long term-they will be better stewards of the land $[104,105]$. Moreover, the assurance effect is also considered to reduce the incentives of farmers to invest resources (including labour and materials) in socially inefficient 
practices aimed at protecting their land from possible takeovers (e.g., building fences, guarding the land) [106] and/or at resolving conflicts over land [107].

The gains from the trade effect extends the assurance effect by considering that, with enhanced transfer rights, the farm-household can benefit from land-related investments, including investments in adoption of practices with climate-smart potential, not only via farming activity but also via land market activity (i.e., via the sale or rental of the land). In other words, by undertaking land-related investments that improve the quality of the land, the value of the asset will increase, resulting in higher land price if rented out or sold $[87,95] .^{16}$

The outside investment effect [96] relates to the positive externalities that particular land uses-including the adoption of CSA practices-can generate and for which a farmer can be compensated (e.g., via the payment for environmental services). In this regard, tenure security can be considered crucially important for both the payor (who might find it inefficient to agree payments if the rights to the land are not clearly defined) and the payee (who might not be willing to undertake land-related investments without the security that she will be the recipient of the compensation).

The community tenure effect [96] relates specifically to areas where traditional (customary) rights to the land are present. In these areas, tenure security can be considered crucially important for the realisation of the community version of the assurance as well as the outside investment effects (and of the collateralisation and gains from trade effects in the cases where customary land can be mortgaged and leased), which may thus create an important foundation for the adoption of CSA at the community level. In other words, and as specified in our extension of the FAO definition of tenure security, individuals require security of tenure but so do groups/communities. In this optic, the rights to the land of communities can be granted and protected. This is consistent with provisions from section nine "Indigenous peoples and other communities with customary tenure systems" of the Voluntary Guidelines on the Responsible Governance of Tenure of Land, Fisheries and Forests in the Context of National Food Security (VGGT) endorsed by the Committee on World Food Security [108] (pp. 14-16). It should be noted that such rights can apply not only to cultivated land but also to forest lands, where sustainable forest management is often jeopardised by the lack of tenure security-as has been witnessed in several lower-income countries $[37,109,110]$. Tenure security within a community can also play an important role in substantially reducing the likelihood of land grabbing by external actors, which have often been found to undermine sustainable land use through deforestation actions and implementation of large-scale cash cropping. There is a consensus in the literature on large-scale land acquisitions upon the positive effect that tenure insecurity exerts on large-scale land investments [111].

Finally, the political stability effect indicates that tenure security, by "providing small farmers with a more significant stake in society" [33] (p. 163) and reducing their fears of dispossession, would reduce potential conflicts between stakeholders and favour political stability [37,94].

A noteworthy aspect relating to tenure reform is the importance it can have in promoting gender equality. Numerous national and global initiatives have been launched in this respect, based on the notion, widely substantiated in the literature $[39,112-114]$ that including gender equality in the provisions for secure land rights (under any of the four land tenure types mentioned above) can lead to substantial improvements in the livelihoods of rural populations, including via CSA adoption [115]. National initiatives include, for instance, the explicit reference to means of advancing women's rights to land in national legislation, policies and programmes (for individual country profiles see, for instance, the FAO gender and land rights database: [116]). International initiatives include the consideration of gender equality as a guiding principle of the VGGT [108], the inclusion of two specific land and gender equality related indicators within the Sustainable Development Goals' Agenda 2030—indicators 1.4.2

16 [87] (p. 374) renames this effect the "realizability effect". 
and 5.A.1 [117], the establishment of a legal assessment tool for gender-equitable land tenure [118] and several advocacy initiatives [119-121].

As indicated in the description of the above-mentioned effects, tenure reform can, via enhanced tenure security, also stimulate the adoption of agricultural practices with climate-smart potential. This is further confirmed by a large number of empirical studies [11,12,67-69,71-73,75-77,80,122,123].

Tenure reforms, by enhancing tenure security, would therefore generate a wide range of beneficial effects, including enhancing the likelihood of CSA adoption and contributing to the attainment of various economic, social and political objectives. The tenure reform pillar is therefore linked to the CSA adoption octagon at the centre of Figure 1 (arrow "2a") and to the 'traditional' objectives box (arrow " $\left.2 b^{\prime \prime}\right)$. In turn, CSA adoption is expected to have positive effects on the CSA objectives (arrow "a"). Therefore, tenure reform can contribute to the achievement of both sets of 'intermediate' objectives (i.e., CSA and 'traditional' objectives) and consequently lead to improvements in the agroecological and socioeconomic conditions of the farms and farm-households (arrows " $\mathrm{c}$ " and " $\mathrm{d}$ ").

To conclude, it must be emphasised that inclusive processes warranting careful attention to, and consideration of, the contextual environment-including not only the state of institutions and governance, but also the existing cultural and social relations and the existing community-level initiatives and demands-are essential in the design of particular tenure reforms. Neglecting such inclusive processes can lead to the realisation of ineffective tenure reforms, as has been the case in a number of countries, notably in Sub-Saharan Africa [87,94,124].

\section{Support Services: Markets, Infrastructure, Rural Advisory Services}

Land reforms can include interventions consisting of enhancing land reform beneficiaries' access to a range of support services. These services are generally directed at facilitating farmers' access to markets (e.g., financial markets, input/output markets, land markets) and to social and economic infrastructure (e.g., rural roads, water supply systems, telecommunication, health and education facilities) - hereafter Markets and Infrastructure (MaI)—as well as at enhancing farmers' access to information, knowledge and technologies (i.e., Rural Advisory Services-RAS). ${ }^{17}$ These support services represent the third and fourth pillars included in the CSLR framework (Figure 1).

Access to these services is also important for smallholder farmers that are not land reform beneficiaries [126]. However, in the presence of agrarian systems with very unequal distribution of land, the demand for infrastructure development, extensive scientific research and the associated advisory services can be deficient [18]. In other words, interventions that redress land inequality, such as land redistribution and/or tenure reform, can generate a stimulus for the demand, and consequent development, of MaI and RAS. As further described below, inadequate (or absent) access to MaI and to RAS on behalf of land reform beneficiaries can limit the efficacy of the land redistribution and/or tenure reform intervention.

Initiatives to foster land reform beneficiaries' access to MaI and to RAS can be viewed as complementary to the first two pillars of the framework. MaI and RAS are also strongly interconnected and thus benefit from combined action. To guarantee, for instance, the success of interventions undertaken to enable land reform beneficiaries' access to financial market services such as index-based insurance, a matching intervention enhancing land reform beneficiaries' information and knowledge upon the functioning of such services and upon how to concretely access such services should also be introduced [127].

In the case of pre-reform unimodal agrarian structures, such as those present in several East Asian countries, favourable MaI conditions and the gradual acquisition of relevant skills, managerial

17 A comprehensive definition of RAS is provided by [125] (p. 3): "systems that should facilitate the access of farmers, their organizations and other market actors to knowledge, information and technologies; facilitate their interaction with partners in research, education, agri-business, and other relevant institutions; and assist them to develop their own technical, organizational and management skills and practices." 
experience and knowledge for tenant farmers in the pre-reform era represented important factors for the economic, social and political success of land reforms in these countries $[46,128]$. Similarly, $\mathrm{MaI}$ and RAS played an important role in enhancing agricultural productivity and output growth in several countries where successful de-collectivisation types of reforms were implemented (e.g., China, Vietnam, a few former USSR countries [18]). Instead, in the presence of bi-modal systems, such as in Latin America, Southern Africa and a minority of Asian countries [51], the need to break-up large landholdings into smaller parcels and to settle farmers (who often had little managerial and technological and market access knowledge) onto these required extensive pre- and post-settlement support interventions, the shortage of which is often seen as one of the reasons for the limited economic, social and political successes of these land reforms [38,49]. A number of other context-specific factors have also contributed to these limited successes. In several Latin American countries, for instance, in the decades that followed the 1961 US-backed Alliance for Progress, the political power of large landowners influenced land reform processes in such a way that these elites resulted as the main beneficiaries of the reforms. In countries such as Ecuador and Colombia, generous subsidies, tax advantages, price support programmes, technological and infrastructural support were skewed towards large-scale farmers, creating an inefficient transition to modern, capitalist, agriculture [34,91,129]. In Chile, the landed elites strongly supported the 1973 Coup which led to the reversal of a large part of the redistribution efforts undertaken under the Frei and Allende governments. ${ }^{18}$ Other relevant factors included "settlements located in remote areas, poor land not well suited to farming poor management and bureaucratic top-down controls, and so forth. These shortcomings are not inherent to land reform as a public policy. Rather, they reflect a lack of commitment and effective political will and, at times, of course, an insufficiency of resources for adequate implementation" [38] (p. 57). In recent years, however, there has been a tendency for several Latin American governments to try and revive land reform efforts, including via market-led land redistribution efforts.

Both MaI and RAS are thus important for the attainment of the 'traditional' objectives of land reformers, and of individual CSA objectives, such as (sustainable) increases in agricultural productivity. ${ }^{19}$ These channels are depicted in Figure 1 by the arrows labelled " $3 a$ " and " $3 b^{\text {" linking }}$ the MaI pillar to the 'intermediate' objectives and by arrows " $4 \mathrm{a}$ " and " $4 \mathrm{~b}$ " linking the RAS pillar to the 'intermediate' objectives.

\subsection{Pillar III: Markets and Infrastructure}

Beyond contributing to increases in agricultural productivity and to the realisation of 'traditional' objectives of land reformers, MaI development can enhance farmers' opportunities to adopt CSA practices and technologies. Therefore, the MaI pillar is also linked to the CSA adoption octagon in Figure 1 (arrow " $3 c^{\prime \prime}$ ). Access to financial markets, including credit and insurance, can generate an important push for farmers to undertake investments in agricultural practices with climate-smart potential, particularly for those farmers who are money-constrained and risk-averse [72,81,130-133]. Facilitating farmers' access to input and output markets can also stimulate adoption of practices with climate-smart potential [73,76,134-136]. Easier access to input markets results in a reduction in the transaction costs linked to the acquisition of information upon CSA practices. Input providers represent an important source of information for farmers throughout the globe, and increasingly so

18 The historical vote that took place in October 2020 in Chile, where an overwhelming majority (78 percent) of voters expressed their will to have the 1980 (Pinochet-Era) constitution re-written, is an indication that the conservative interests perpetuating inequality in the country are likely to be overhauled by a new democratic movement ignited by the quest for social rights and equality. Beyond pressing rights such as housing, healthcare, and education, alternative rights to water, to land and enhanced environmental rights compared to those present in the 1980 constitution (and subsequent revisions) may well feature among the key themes that the Chileans elected to form the constitutional convention will be tasked to include in the new constitution.

19 The same caveat reported in Section 2 (Pillar I Land Redistribution) above applies here: the agricultural productivity gains derived from MaI and RAS interventions that are not determined by CSA adoption may or may not be sustainable. 
for small-scale farmers in lower-income country settings. These often lack the myriad of information sources that large-scale farmers in higher-income countries are exposed to and therefore can benefit significantly from information provided by input suppliers $[137,138]$. Indeed, easier access to input markets also reduces the transaction costs associated to the acquisition of the necessary inputs required for the implementation of CSA practices (e.g., seeds, equipment). Similarly, enhancing farmers' access to output markets can reduce transaction costs related to the sale of produce (reducing therefore the so-called "marketability constraint" [66] (p. 83)) and enhance the likelihood of adoption of practices with climate-smart potential, particularly those practices that result in more diverse production, including the use of mixed cropping systems, crop rotation, intercropping and agroforestry.

Measures to facilitate access to these markets can include redressing inequalities in the provision of subsidies, price support programmes and technological and infrastructural support away from large-scale farmers to create a business environment in which small-scale land reform beneficiaries can flourish $[54,57,139]$. Infrastructure development represents both a means to enhance market access and to foster CSA adoption. Investments in infrastructure can include, for example, construction/rehabilitation of roads, bridges, marketplaces, storage and processing facilities, power plants and electricity networks, water supply systems for irrigation, as well as information and communication technology infrastructure. These are measures that can be taken to facilitate farmers' market access $[72,140]$. They also represent interventions that can spur adoption of practices with climate-smart potential, such as sustainable irrigation methods, hermetic storage, crop diversification and changes in crop calendars, among others [2,81,141,142].

In summary, MaI can play a critical role in enhancing the likelihood of CSA adoption, and in contributing to the realisation of the 'intermediate' objectives outlined in the CSLR framework. Land reformers should therefore carefully assess the state of MaI in the context of the land reform and consider the viability of various MaI intervention options and strategies, as well as the risks associated with a lack of intervention on MaI for the overall effectiveness of the land reform.

\subsection{Pillar IV: Rural Advisory Services}

Over the past decades there has been an evolution in the terminology used to describe advisory services provided to farmers, and in the institutional arrangements and methods used for the financing and delivery of these services [143]. A brief overview of the dynamics witnessed in the field of advisory services is therefore provided prior to discussing the channels linking these to CSA adoption. The terminology has evolved from the commonly used agricultural extension concept to agricultural advisory services and, most recently, Rural Advisory Services (RAS). This reflects a shift in the type of advisory support provided to farmers, in the way that support is conceived and provided to farmers and in the type of stakeholders involved in the process. During the 1950-60s, agricultural extension was conceived as a linear top-down, often one-size-fits-all, transfer of technology (ToT) from a technically knowledgeable agent (commonly an employee of a public institution) to the farmer with the objective of increasing production levels. Subsequently, the understanding that this type of model gave rise to several weaknesses, including the lack of crucial feedback linkages between the farmers and the providers of the extension support, led to the development of new approaches such as the Training and Visit (T\&V) system [144]. However, this system, which was strongly advocated by the World Bank and implemented between 1974 and 1998 in a significant number of countries, proved financially unsustainable and its impact difficult to demonstrate. This led to the collapse of $T \& V$ at the end of the 20th century in most countries [145]. The model that emerged in the early 2000s was the Agricultural Knowledge and Information System for Rural Development (AKIS/RD). This model, conceptualized and promoted by the World Bank and FAO, explicitly considered the importance of feedback loops amongst the three crucial actors of the knowledge triangle, namely agricultural educators, researchers and extensionists, as well as with farmers, which were placed at the "heart of the knowledge triangle" [146] (p. 2). This framework was thus innovative in that it radically changed the dynamics of the relationships between actors, setting at the centre of the stage the farmers, 
thus rendering the system more demand-driven, and making "agricultural research, extension and education appear as equal partners" [147] (p. 585). Moreover, it explicitly considered the possibility of having public and private actors as well as civil society "participate meaningfully in decisions about the design, implementation, funding and evaluation of education, research and extension programmes" [146] (p. 14). AKIS/RD also recognized, and placed an emphasis on, providing different solutions to different farm households based on their different agroecological and socioeconomic conditions, as well as on the need to address challenges beyond those related to a deficit in agricultural production. From the perspective of the advisory services provided to farmers, this implied considering aspects such as environmental sustainability, health and nutrition, post-harvest handling, marketing and integration in value chains, access to inputs and financial services and even off-farm activities. The framework began contemplating a more holistic approach to advisory services in support of rural populations and their livelihoods. It is in a similar vein that the Agricultural Innovation Systems (AIS) came to light and that international initiatives such as the Global Forum for Rural Advisory Services (GFRAS) were established. The AIS emerged in recognition of the rapid development of Information and Communication Technologies (ICTs) and placed a renewed focus on innovation. In the literature, AIS is often depicted as an expansion of AKIS/RD: in AIS the knowledge triangle framework is augmented by explicitly including other stakeholders (such as consumers, agroprocessors, exporters, producer organizations, input suppliers) due to their capacity to create and spread innovations and knowledge relevant to farmers and rural populations [148]. More recently, a framework was conceptualised by researchers at the International Food Policy Research Institute (IFPRI) expanding the AIS model to include contextual factors as key inputs for the design of performant agricultural advisory services. The double-sided interaction between farm households and advisory services is maintained in this framework and is recognized as essential for attaining impact [143]. ${ }^{20}$

Land reforms are expected to play a determinant role in the design and preparation of RAS, notably those destined to land reform beneficiaries. Of course, RAS are commonly present also in contexts where land reforms are not being planned or implemented. Nevertheless, land reforms can play a determining role in tailoring RAS to beneficiary farmers' conditions and demands. This is showcased in Figure 1, where the agroecological and socioeconomic conditions box at the bottom of the figure feeds back to the RAS pillar (arrow "B"). In effect, the specific agroecological conditions pertaining to the beneficiary farmer's land and the socioeconomic conditions of the farmer are key elements that are to be considered when designing relevant RAS [151,152]. The type of RAS demanded by land reform beneficiary farmers will also be influenced by the pre-reform tenure arrangements existing in the specific context where the land reform is being implemented. In the case of redistributive types of reforms, the quantity and nature of the RAS to be provided will be substantially larger and more complex compared to, for instance, contexts where land reform beneficiaries were already farm operators in the pre-reform era [19]. This is due to the fact that under redistributive types of reform a more radical paradigm shift in the provision of RAS will be required. A transition will need to be planned and implemented from a context where RAS are provided to a given set of farmers (most likely experienced, presumably large, commercially oriented) to a state in which RAS need to be provided to a significantly larger number of farmers with presumably different characteristics (e.g., less experienced or with no experience, particularly farm management experience, with smaller landholdings, primarily oriented at subsistence agriculture). The quantity and nature of RAS demanded by farmers will be, at least in part, determined by the agroecological and socioeconomic conditions of the farm and farm-household and by the quantity and nature of previous farming experience, including experience in agricultural production and farm management $[153,154]$.

20 It should be noted, in passing, that although this overview of the evolution of advisory services describes a close to linear process, whereby models such as the ToT or T\&V appear as obsolete and no longer present, in practice advisory service providers continue to perpetuate traditional methods in several rural areas of lower-income countries (see, for instance, $[149,150])$. 
This design phase of the RAS system needs to be participatory and inclusive, with the involvement of the various relevant public institutions and of the farmers as key stakeholders, who appear in Figure 1 in the form of an ellipse at the centre of the figure, but also of a multitude of other actors that can contribute according to their comparative advantages to the design and subsequent provision of RAS $[143,144,155]$. These various stakeholders, originating from the (national and international) public and private sector, include financial institutions and financial service providers, agricultural research institutions, education and training organisations, agricultural extension service providers, climate and weather information institutions, information and telecommunication companies, input suppliers and farmer organisations, among others, who interact and act in support of farmers' livelihoods enhancement.

In turn, the appropriate design and provision of RAS by multiple stakeholders is expected to stimulate farmers' adoption of practices with climate-smart potential. This channel is portrayed in Figure 1 by the arrow " $4 \mathrm{c}$ " linking the RAS pillar to the CSA adoption octagon. There is longstanding evidence in the literature that extension services can foster technology adoption in agricultural production, mostly by increasing farmers' exposure to, and information on, these technologies [79]. More recent research has shown that RAS, including but not limited to extension services targeting agricultural production, can represent a key foundation for smallholders' adoption of agricultural practices and technologies with climate-smart potential $[2,135,156,157]$. The expansion of advisory services' objectives beyond increasing agricultural production mentioned above has led to the elaboration of guidelines and manuals promoting the adoption of CSA practices and technologies via advisory services (see, for instance, [156-161]). Recent empirical evidence confirms the importance that RAS can have on increasing farmers' awareness of, and information on, practices and technologies with climate-smart potential, thereby positively contributing to adoption of such practices $[14,66,74,141,162-164]$. Indeed, in order for RAS to be impactful, it is not only important that the quantity of advisory services be sufficient, but it is also essential that the RAS provided be of considerable quality [72,165]. In addition, more specific RAS, directed for instance at enhancing smallholder farmers' knowledge upon options and strategies to access input/output and/or financial markets, can prove important to complement MaI interventions and increase the likelihood of CSA adoption [81,164]. Similarly, providing farmers with timely and localised weather-related advisory services can enable farmers to reduce short-term risks (e.g., lack or excess rainfall at key crop growth stages leading to crop losses) by undertaking specific actions (e.g., changing seeding/fertiliser application dates, setting up irrigation systems). In an era of global warming, these weather-related advisory services should be coupled not only with early warning systems, which can play crucial roles in reducing crop losses (and loss of life), but also with interventions that provide farmers with accurate and timely information and explanations on climate developments. Such climate-related RAS, which would ideally be localised and participatory, integrating local farmer perceptions and knowledge with scientific data, could better prepare farmers to consider and select the more appropriate medium to long term risk-reducing and livelihood-enhancing strategies, including adoption of practices/technologies with climate-smart potential [69,74,152,166,167].

These relations help uncover the second iterative process of the CSLR framework, which is described in the conclusion of this section. We have seen that RAS have the potential to contribute not only to the attainment of 'traditional' objectives of land reformers, but also to enhance CSA adoption, thereby generating beneficial effects on the three CSA objectives. Now, the (partial) achievement of both sets of 'intermediate' objectives (i.e., CSA and 'traditional' objectives) generates improved agroecological and socioeconomic conditions of the farm and farm-household. In turn, this new state of agroecological and socioeconomic conditions is expected to create a revised demand for RAS on behalf of farmers, which could lead to renewed adoption of CSA, to further positive effects on the 'intermediate' objectives of land reformers and thus to further improved agroecological and socioeconomic conditions. 


\section{Conclusions}

In an era of global warming, the numerous challenges faced in rural areas of lower-income countries are being exacerbated by the effects of climate change. Effective policies at the national and local level are required to tackle these challenges whilst ensuring the best possible use of the (limited) resources available. In this sense, policy initiatives can be sought to enhance farm-households' adoption of agricultural practices and technologies that preserve ecosystem services without depressing agricultural production and avoiding environmental resource overexploitation [168]. The CSLR framework introduced in this paper presents an innovative way to conceptualise how land reform programmes can generate beneficial effects not only on the attainment of the more 'traditional' objectives of land reformers (be they social, economic, political) but also of objectives related to environmental sustainability.

The paper describes relevant channels through which 'traditional' objectives of land reformers, as well as the three CSA objectives (sustainable increases in agricultural productivity, climate change adaptation and climate change mitigation) can be attained. The importance of both redistributive and tenure types of reforms, as well as the enhancement of opportunities for land reform beneficiaries to access a wide range of support services are advanced in the paper as the key drivers for the attainment of these 'intermediate' objectives. In turn, the (partial) achievement of 'intermediate' objectives is described as generating positive effects on the 'ultimate' objective of land reformers within the CSLR framework: improved agroecological and socioeconomic conditions of rural areas and populations. Furthermore, two iterative processes are highlighted in the paper, indicating the possibility of a gradual process towards the realisation of this 'ultimate' objective.

The theory and evidence discussed in the paper indicate that interventions related to individual pillars of the CSLR framework can generate positive effects on the attainment of the 'intermediate' objectives of land reformers and may therefore be advisable. However, in order to further enhance the likelihood of widespread CSA adoption, policymakers should carefully assess and consider whether opportunities exist to intervene on the four policy levers (i.e., on the four pillars of the CSLR framework).

In terms of its potential use, the CSLR framework is intended for both applied research and policy. On the former, the framework can be utilised as a basis for the realisation of empirical studies on the specific channels depicted within it in different land reform contexts. This would provide further context-specific validation or refutation of the propositions included in this paper, thereby generating a more solid evidence base that policymakers can rely upon. Moreover, researchers can adapt the framework to study a variety of policy interventions, beyond land reforms, that are aimed at supporting specific groups within a country's population, such as refugees, ethnic minorities or other vulnerable groups, in implementing agricultural practices with climate-smart potential and in attaining economic, social, political and environmental objectives.

On the policy front, the framework can serve as a conceptual guide in the (re)design phase of a land reform programme. It can be used to assist policymakers in decision-making processes related to the CSLR policy levers, both in terms of mode and extent of action. Moreover, the CSLR framework can be used as a basis for the preparation of monitoring tools that can be employed during the implementation phase of the land reform programme in order to track progress (and uncover difficulties) related to the achievement of the 'intermediate' and 'ultimate' objectives outlined in the framework. Finally, elements of the CSLR framework can be used to support efforts undertaken by governments to raise the financial resources necessary to complement budgetary resources allocated to the implementation of land reform programmes. In effect, by explicitly integrating environmental objectives linked to climate change within the land reform programme, additional financing windows can be explored, including multilateral climate funds (e.g., Green Climate Fund, Green Environment Facility Funds, Adaptation Fund), climate funds linked to international development banks (e.g., World Bank, African Development Bank, Asian Development Bank, InterAmerican Development Bank) and funds sourced through the National Determined Contribution (NDC) partnership [169]. 
Indeed, both of these intended uses of the framework are ultimately directed at farm-households. Farmers are at the centre of the CSLR framework and adequate platforms and systems must exist (or be created) to ensure that farmers can actively participate in local and national land reform processes.

In terms of its limitations, the CSLR framework, by being purposefully generic, does not include a specific diagnostic approach applicable to the exact circumstances of a given individual country context. In other words, the framework offers a departure point from which further context-specific analyses can be undertaken. Moreover, for reasons of space and focus, this study does not include a detailed analysis of the various additional socio-economic policy interventions, beyond land reforms, that may contribute to farm-households' adoption of CSA (be it in the agricultural, health, education sector). These may indeed represent relevant complements or substitutes to land reform interventions depending on the specific conditions faced by populations within the different country contexts.

Author Contributions: Conceptualization, A.R., Y.G., G.R.; writing-original draft preparation, A.R.; writing-review and editing, Y.G., G.R., A.R.; visualization, A.R.; supervision, Y.G., G.R.; project administration, Y.G. All authors have read and agreed to the published version of the manuscript.

Funding: The APC was funded by The University of Reading. The corresponding author has received funding to conduct this research from the Edith Mary Gayton bequest managed by the Farm Management Unit, University of Reading.

Conflicts of Interest: The authors declare no conflict of interest.

\section{References}

1. FAO. Climate-Smart Agriculture Sourcebook, 2nd ed.; FAO: Rome, Italy, 2017.

2. IPCC. Climate Change and Land: An IPCC Special Report on Climate Change, Desertification, Land Degradation, Sustainable Land Management, Food Security, and Greenhouse Gas Fluxes in Terrestrial Ecosystems; IPCC: Geneva, Switzerland, 2019. Available online: https:/www.ipcc.ch/srccl/cite-report/ (accessed on 23 November 2020).

3. FAO. Food Security and Agricultural Mitigation in Developing Countries: Options for Capturing Synergies; FAO: Rome, Italy, 2009.

4. FAO. Climate-Smart Agriculture: Policies, Practices and Financing for Food Security, Adaptation and Mitigation; FAO: Rome, Italy, 2010.

5. Aggarwal, P.K.; Jarvis, A.; Campbell, B.M.; Zougmoré, R.B.; Khatri-Chhetri, A.; Vermeulen, S.J.; Loboguerrero, A.M.; Sebastian, L.S.; Kinyangi, J.; Bonilla-Findji, O.; et al. The climate-smart village approach: Framework of an integrative strategy for scaling up adaptation options in agriculture. Ecol. Soc. 2018, 23. [CrossRef]

6. Sova, C.A.; Grosjean, G.; Baedeker, T.; Nguyen, T.N.; Wallner, M.; Nowak, A.; Corner-Dolloff, C.; Girvetz, E.; Laderach, P.; Lizarazo, M. Bringing the Concept of Climate-Smart Agriculture to Life: Insights from CSA Country Profiles Across Africa, Asia, and Latin America; World Bank: Washington, DC, USA, 2018.

7. World Bank. World Bank Group Climate Change Action Plan; World Bank: Washington, DC, USA, 2016.

8. World Bank. Climate-Smart Agriculture Investment Plan Bangladesh; World Bank: Washington, DC, USA, 2019.

9. World Bank. Climate-Smart Agriculture Investment Plan Côte d'Ivoire; World Bank: Washington, DC, USA, 2019.

10. Abegunde, V.O.; Sibanda, M.; Obi, A. The Dynamics of Climate Change Adaptation in Sub-Saharan Africa: A Review of Climate-Smart Agriculture among Small-Scale Farmers. Climate 2019, 7, 132. [CrossRef]

11. Asfaw, S.; McCarthy, N.; Lipper, L.; Arslan, A.; Cattaneo, A. What determines farmers' adaptive capacity? Empirical evidence from Malawi. Food Secur. 2016, 8, 643-664. [CrossRef]

12. Kpadonou, R.A.B.; Owiyo, T.; Barbier, B.; Denton, F.; Rutabingwa, F.; Kiema, A. Advancing climate-smart-agriculture in developing drylands: Joint analysis of the adoption of multiple on-farm soil and water conservation technologies in West African Sahel. Land Use Policy 2017, 61, 196-207. [CrossRef]

13. McCarthy, N.; Lipper, L.; Branca, G. Climate-Smart Agriculture: Smallholder Adoption and Implications for Climate Change Adaptation and Mitigation; FAO: Rome, Italy, 2011.

14. Vecchio, Y.; Agnusdei, G.P.; Miglietta, P.P.; Capitanio, F. Adoption of Precision Farming Tools: The Case of Italian Farmers. Int. J. Environ. Res. Public Health 2020, 17, 869. [CrossRef] [PubMed] 
15. Dunnett, A.; Shirsath, P.B.; Aggarwal, P.K.; Thornton, P.; Joshi, P.K.; Pal, B.D.; Khatri-Chhetri, A.; Ghosh, J. Multi-objective land use allocation modelling for prioritizing climate-smart agricultural interventions. Ecol. Model. 2018, 381, 23-35. [CrossRef]

16. Banerjee, A. Land Reforms: Prospects and Strategies; MIT, Department of Economics: Cambridge, UK, 1999.

17. Griffin, K.; Rahman Khan, A.; Ickowitz, A. Poverty and the Distribution of Land. J. Agrar. Chang. 2002, 2, 279-330. [CrossRef]

18. Lipton, M. Land Reform in Developing Countries: Property Rights and Property Wrongs; Routledge: London, UK; New York, NY, USA, 2009.

19. Binswanger-Mkhize, H.P.; Bourguignon, C.; Van den Brink, R. Agricultural Land Redistribution: Toward Greater Consensus; World Bank: Washington, DC, USA, 2009.

20. African Union; African Development Bank; United Nations Economic Commission for Africa. Framework and Guidelines on Land Policy in Africa-Land Policy in Africa: A Framework to Strengthen Land Rights, Enhance Productivity, and Secure Livelihoods; AUC-ECA-AfDB: Adis Ababa, Ethiopia, 2010.

21. Cohen, S.I. Agrarian Structures and Agrarian Reform-Exercises in Development Theory and Policy; Martinus Nijhoff Social Sciences Division: Leiden, The Netherlands, 1978.

22. Raup, P.M. The Contribution of Land Reforms to Agricultural Development: An Analytical Framework. Econ. Dev. Cult. Chang. 1963, 12,1-21. [CrossRef]

23. United Nations. Progress in Land Reform, Third Report; United Nations: New York, NY, USA, 1962.

24. Ciparisse, G. (Ed.) Multilingual Thesaurus on Land Tenure; FAO: Rome, Italy, 2003.

25. FAO. Land tenure and rural development. Land Tenure Stud. 2002, 3, 1-50.

26. Ciamarra, U.P. State-led and market-assisted land reforms: History, theory, and insight from the Philippines. In Proceedings of the Leuven 8th Spring Meeting of Young Economists, Leuven, Belgium, 3-5 April 2003.

27. Albertus, M. Autocracy and Redistribution; Cambridge University Press: Cambridge, UK, 2015.

28. Tuma, E.H. Twenty-Six Centuries of Agrarian Reform: A Comparative Analysis; University of California Press: Berkeley, CA, USA, 1965.

29. Adams, M. Breaking Ground: Development Aid for Land Reform; Overseas Development Institute (ODI): London, UK, 2000.

30. Deininger, K. Land Policies for Growth and Poverty Reduction; World Bank: Washington, DC, USA, 2003.

31. FAO. Report of the International Conference on Agrarian Reform and Rural Development (ICARRD); FAO: Rome, Italy, 2006.

32. Stiglitz, J. Distribution, efficiency and voice: Designing the second generation of reforms. In Proceedings of the Conference on Asset Distribution, Poverty and Economic Growth, Brasilia, Brazil, 14 July 1998.

33. Dixon-Gough, R.W.; Bloch, P.C. Role of the State and Individual in Sustainable Land Management; Ashgate Publishing Group: Aldershot, UK, 2006.

34. Kay, C. Latin America's agrarian reform: Lights and shadows. Land ReformLand Settl. Coop. 1998, 2, 9-31.

35. King, R. Land Reform: A World Survey; Routledge: New York, NY, USA, 2019.

36. Boyce, J.K.; Rosset, P.; Stanton, E.A. Land Reform and Sustainable Development. Political Econ. Res. Inst. Work. Pap. Ser. 2005, 98, 1-22.

37. Colchester, M.; Lohmann, L. The Struggle for Land and the Fate of Forests; World Rainforest Movement: Penang, Malaysia, 1993.

38. Dorner, P. Latin American Land Reforms in Theory and Practice: A Retrospective Analysis; University of Wisconsin Press: Madison, WI, USA, 1992.

39. Jacobs, S. Agrarian reforms. Curr. Sociol. 2013, 61, 862-885. [CrossRef]

40. Jabareen, Y. Building a Conceptual Framework: Philosophy, Definitions, and Procedure. Int. J. Qual. Methods 2009, 8, 49-62. [CrossRef]

41. Zhu, E.; Lilienthal, A.; Shluzas, L.A.; Masiello, I.; Zary, N. Design of Mobile Augmented Reality in Health Care Education: A Theory-Driven Framework. JMIR Med. Educ 2015, 1, e10. [CrossRef]

42. Eizenberg, E.; Jabareen, Y. Social Sustainability: A New Conceptual Framework. Sustainability 2017, 9, 68. [CrossRef]

43. Nikolakis, W.; John, L.; Krishnan, H. How Blockchain Can Shape Sustainable Global Value Chains: An Evidence, Verifiability, and Enforceability (EVE) Framework. Sustainability 2018, 10, 3926. [CrossRef]

44. Kostoska, O.; Kocarev, L. A Novel ICT Framework for Sustainable Development Goals. Sustainability 2019, 11, 1961. [CrossRef] 
45. Dlouhá, J.; Heras, R.; Mulà, I.; Salgado, F.P.; Henderson, L. Competences to Address SDGs in Higher Education-A Reflection on the Equilibrium between Systemic and Personal Approaches to Achieve Transformative Action. Sustainability 2019, 11, 3664. [CrossRef]

46. Binswanger, H.P.; Deininger, K. South African land policy: The legacy of history and current options. World Dev. 1993, 21, 1451-1475. [CrossRef]

47. Williamson, I.; Enemark, S.; Wallace, J.; Rajabifard, A. Land Administration for Sustainable Development; Esri Press: Redlands, CA, USA, 2010.

48. Borras, S.M. Questioning Market-Led Agrarian Reform: Experiences from Brazil, Colombia and South Africa. J. Agrar. Chang. 2003, 3, 367-394. [CrossRef]

49. Deininger, K. Making Negotiated Land Reform Work: Initial Experience from Colombia, Brazil and South Africa. World Dev. 1999, 27, 651-672. [CrossRef]

50. Pereira, J.M.M.; Fajardo, D. The World Bank's 'Market Assisted Land Reform' in Colombia and Brazil (1994-2002). Rev. Bras. De História 2015, 35. [CrossRef]

51. Barraclough, S.L. Land Reform in Developing Countries: The Role of the State and Other Actors; United Nations Research Institute for Social Development: Geneva, Switzerland, 1999.

52. Aghion, P.; Caroli, E.; Garcia-Penalosa, C. Inequality and Economic Growth: The Perspective of the New Growth Theories. J. Econ. Lit. 1999, 37, 1615-1660. [CrossRef]

53. Deininger, K.; Squire, L. New ways of looking at old issues: Inequality and growth. J. Devel. Econ. 1998, 57, 259-287. [CrossRef]

54. Van den Brink, R.; Binswanger, H.; Bruce, J.W.; Thomas, G.; Byamugisha, F. Consensus, Confusion, and Controversy-Selected Land Reform Issues in Sub-Saharan Africa; World Bank: Washington, DC, USA, 2005.

55. IFPRI. Transforming the Rural Nonfarm Economy - Opportunities and Threats in the Developing World; Haggblade, S., Hazell, P.B., Reardon, T., Eds.; John Hopkins University Press: Baltimore, MD, USA, 2007.

56. Maxwell, D.; Wiebe, K.D. Land Tenure and Food Security: A Review of Concepts, Evidence, and Methods; Land Tenure Center, University of Wisconsin-Madison: Madison, WI, USA, 1998.

57. Binswanger, H.P.; Deininger, K.; Feder, G. Power, distortions, revolt and reform in agricultural land relations. In Handbook of Development Economics; Elsevier: Amsterdam, The Netherlands, 1995; Volume 3, pp. 2659-2772.

58. Sen, A. Development As Freedom; Alfred A. Knopf: New York, NY, USA, 1999.

59. Dorward, A. Farm size and productivity in Malawian smallholder agriculture. J. Devel. Stud. 1999, 35, 141-161. [CrossRef]

60. Sender, J.; Johnston, D. Searching for a Weapon of Mass Production in Rural Africa: Unconvincing Arguments for Land Reform. J. Agrar. Chang. 2004, 4, 142-164. [CrossRef]

61. Cornia, G. Farm size, land yields and the agricultural production function: An analysis for fifteen developing countries. World Dev. 1985, 13, 513-534. [CrossRef]

62. Berry, R.A.; Cline, W.R. Agrarian Structure and Productivity in Developing Countries: A Study Prepared for the International Labour Office Within the Framework of the World Employment Programme; John Hopkins University Press: Baltimore, MD, USA, 1979.

63. Eastwood, R.; Lipton, M.; Newell, A. Farm Size. In Handbook of Agricultural Economics; Evenson, R., Pingali, P., Eds.; Elsevier: Amsterdam, The Netherlands, 2010; Volume 4, pp. 3323-3397.

64. Carletto, C.; Savastano, S.; Zezza, A. Fact or artifact: The impact of measurement errors on the farm size-productivity relationship. J. Devel. Econ. 2013, 103, 254-261. [CrossRef]

65. Carter, M. Identification of the Inverse Relationship between Farm Size and Productivity: An Empirical Analysis of Peasant Agricultural Production. Oxf. Econ. Pap. 1984, 36, 131-145. [CrossRef]

66. Arslan, A.; McCarthy, N.; Lipper, L.; Asfaw, S.; Cattaneo, A. Adoption and intensity of adoption of conservation farming practices in Zambia. Agric. Ecosyst. Environ. 2014, 187, 72-86. [CrossRef]

67. Asfaw, S.; Coromaldi, M.; Lipper, L. Adaptation to Climate Change and Food Security: Evidence from Smallholder Farmers in Ethiopia; FAO: Rome, Italy, 2015.

68. Asfaw, S.; Di Battista, F.; Lipper, L. Food Security Impact of Agricultural Technology Adoption under Climate Change: Micro-Evidence from Niger; FAO: Rome, Italy, 2015.

69. Di Falco, S.; Veronesi, M. How Can African Agriculture Adapt to Climate Change? A Counterfactual Analysis from Ethiopia. Land Econ. 2013, 89, 743-766. [CrossRef]

70. Kassie, M.; Zikhali, P.; Pender, J.; Köhlin, G. The Economics of Sustainable Land Management Practices in the Ethiopian Highlands. J. Agric. Econ. 2010, 61, 605-627. [CrossRef] 
71. Kassie, M.; Jaleta, M.; Shiferaw, B.; Mmbando, F.; Mekuria, M. Adoption of interrelated sustainable agricultural practices in smallholder systems: Evidence from rural Tanzania. Technol. Forecast. Soc. Chang. 2013, 80, 525-540. [CrossRef]

72. Teklewold, H.; Kassie, M.; Shiferaw, B. Adoption of Multiple Sustainable Agricultural Practices in Rural Ethiopia. J. Agric. Econ. 2013, 64, 597-623. [CrossRef]

73. Teklewold, H.; Mekonnen, A.; Kohlin, G. Climate change adaptation: A study of multiple climate-smart practices in the Nile Basin of Ethiopia. Clim. Dev. 2019, 11, 180-192. [CrossRef]

74. Arslan, A.; Belotti, F.; Lipper, L. Smallholder productivity and weather shocks: Adoption and impact of widely promoted agricultural practices in Tanzania. Food Policy 2017, 69, 68-81. [CrossRef]

75. Lawin, K.G.; Tamini, L.D. Land Tenure Differences and Adoption of Agri-Environmental Practices: Evidence from Benin. J. Dev. Stud. 2018, 55, 177-190. [CrossRef]

76. Nyangena, W. Social determinants of soil and water conservation in rural Kenya. Environ. Dev. Sustain. 2007, 10, 745-767. [CrossRef]

77. Pino, G.; Toma, P.; Rizzo, C.; Miglietta, P.P.; Peluso, A.M.; Guido, G. Determinants of Farmers' Intention to Adopt Water Saving Measures: Evidence from Italy. Sustainability 2017, 9, 77. [CrossRef]

78. Makate, C.; Makate, M.; Mango, N.; Siziba, S. Increasing resilience of smallholder farmers to climate change through multiple adoption of proven climate-smart agriculture innovations. Lessons from Southern Africa. J. Environ. Manag. 2019, 231, 858-868. [CrossRef]

79. Feder, G.; Just, R.E.; Zilberman, D. Adoption of Agricultural Innovations in Developing Countries: A Survey. Econ. Devel. Cult. Chang. 1985, 33, 255-298. [CrossRef]

80. Abdulai, A.; Owusu, V.; Goetz, R. Land tenure differences and investment in land improvement measures: Theoretical and empirical analyses. J. Devel. Econ. 2011, 96, 66-78. [CrossRef]

81. Hassan, R.M.; Nhemachena, C. Determinants of African farmers' strategies for adapting to climate change: Multinomial choice analysis. Afr. J. Agric. Resour. Econ. 2008, 2, 83-104.

82. Pender, J.; Gebremedhin, B. Determinants of Agricultural and Land Management Practices and Impacts on Crop Production and Household Income in the Highlands of Tigray, Ethiopia. J. Afr. Econ. 2007, 17, 395-450. [CrossRef]

83. Arslan, A.; McCarthy, N.; Lipper, L.; Asfaw, S.; Cattaneo, A.; Kokwe, M. Food Security and Adaptation Impacts of Potential Climate Smart Agricultural Practices in Zambia; FAO: Rome, Italy, 2015.

84. Baron, J.B. Rescuing the bundle-of-rights metaphor in property law. Univ. Cincinnati Law Rev. 2013, 82, 57-102.

85. Johnson, D.R. Reflections on the Bundle of Rights. Vt. Law Rev. 2007, 32, 247-272.

86. Rights and Resources Initiative. What Rights? A Comparative Analysis of Developing Countries' National Legislation on Community and Indigenous Peoples' Forest Tenure Rights; Rights and Resources Initiative: Washington, DC, USA, 2012.

87. Brasselle, A.-S.; Gaspart, F.; Platteau, J.-P. Land tenure security and investment incentives: Puzzling evidence from Burkina Faso. J. Devel. Econ. 2002, 67, 373-418. [CrossRef]

88. Holden, S.; Otsuka, K.; Deininger, K. Land Tenure Reform in Asia and Africa: Assessing Impacts on Poverty and Natural Resource Management; Palgrave Macmillan: London, UK; New York, NY, USA, 2013.

89. Kasimbazi, E. Land Tenure and Rights for Improved Land Management and Sustainable Development; UNCCD: Bonn, Germany, 2017.

90. Alden Wily, L. Collective Land Ownership in the 21st Century: Overview of Global Trends. Land 2018, 7, 68. [CrossRef]

91. De Janvry, A. The agrarian question and reformism in Latin America; John Hopkins University Press: Baltimore, MD, USA, 1981.

92. Deininger, K.; Feder, G. Land Registration, Governance, and Development: Evidence and Implications for Policy. World Bank Res. Obs. 2009, 24, 233-266. [CrossRef]

93. De Janvry, A.; Key, N.D.; Sadoulet, E. Agricultural and Rural Development Policy in Latin America: New Directions and New Challenges; FAO: Rome, Italy, 1997; Volume 2.

94. Platteau, J.P. The evolutionary theory of land rights as applied to sub-Saharan Africa: A critical assessment. Devel. Chang. 1996, 27, 29-86. [CrossRef]

95. Besley, T. Property Rights and Investment Incentives: Theory and Evidence from Ghana. J. Polit. Econ. 1995, 103, 903-937. [CrossRef] 
96. McCarthy, N.; Brubaker, J. Climate-Smart Agriculture and Resource Tenure in SubSaharan Africa: A Conceptual Framework; FAO: Rome, Italy, 2014.

97. Byamugisha, F.F. The Effects of Land Registration on Financial Development and Economic Growth: A Theoretical and Conceptual Framework; World Bank: Washington, DC, USA, 1999.

98. De Soto, H. The Mystery of Capital: Why Capitalism Triumphs in the West and Fails Everywhere Else; Basic Books: New York, NY, USA, 2000.

99. Higgins, D.; Balint, T.; Liversage, H.; Winters, P. Investigating the impacts of increased rural land tenure security: A systematic review of the evidence. J. Rural Stud. 2018, 61, 34-62. [CrossRef]

100. Lawry, S.; Samii, C.; Hall, R.; Leopold, A.; Hornby, D.; Mtero, F. The impact of land property rights interventions on investment and agricultural productivity in developing countries: A systematic review. J. Dev. Eff. 2017, 9, 61-81. [CrossRef]

101. Meinzen-Dick, R.; Mwangi, E. Cutting the web of interests: Pitfalls of formalizing property rights. Land Use Policy 2009, 26, 36-43. [CrossRef]

102. Binswanger, H.P.; Rosenzweig, M.R. Behavioural and material determinants of production relations in agriculture. J. Dev. Stud. 1986, 22, 503-539. [CrossRef]

103. Domeher, D.; Yeboah, E.; Ellis, F. Formal property titles or more? Perspectives from Ghana's financial institutions. Afr. Rev. Econ. Financ. 2018, 10, 243-273.

104. Dekker, H. In Pursuit of Land Tenure Security-Essays on Land Reform and Land Tenure; Pallas Publications: Amsterdam, The Ntherlands, 2005.

105. Thiesenhusen, W.C. Implications of the Rural Land Tenure System for the Environmental Debate: Three Scenarios. J. Dev. Areas 1991, 26, 1-24.

106. Besley, T.; Ghatak, M. Property Rights and Economic Development. In Handbook of Development Economics; Rodrik, D., Rosenzweig, M., Eds.; Elsevier: Amsterdam, The Netherlands, 2010; Volume 5, pp. 4525-4595.

107. Deininger, K.; Castagnini, R. Incidence and impact of land conflict in Uganda. J. Econ. Behav. Organ. 2006, 60, 321-345. [CrossRef]

108. FAO. Voluntary Guidelines on the Responsible Governance of Tenure of Land, Fisheries and Forests in the Context of National Food Security; FAO: Rome, Italy, 2012.

109. FAO. Understanding forest tenure in South and Southeast Asia; FAO: Rome, Italy, 2006.

110. Quan, J.; Dyer, N. Climate Change and Land Tenure: The Implications of Climate Change for Land Tenure and Land Policy; FAO: Rome, Italy, 2008.

111. De Maria, M. Understanding Land in the Context of Large-Scale Land Acquisitions: A Brief History of Land in Economics. Land 2019, 8, 15. [CrossRef]

112. Deere, C.D. Women's land rights, rural social movements, and the state in the 21st-century Latin American agrarian reforms. J. Agrar. Chang. 2017, 17, 258-278. [CrossRef]

113. Meinzen-Dick, R.; Quisumbing, A.; Doss, C.; Theis, S. Women's land rights as a pathway to poverty reduction: Framework and review of available evidence. Agric. Syst. 2019, 172, 72-82. [CrossRef]

114. Quan, J. Land Access in the 21st Century: Issues, Trends, Linkages and Policy Options; FAO: Rome, Italy, 2006.

115. World Bank; FAO; IFAD. Gender in Climate-Smart Agriculture-Module 18 for the Gender in Agriculture Sourcebook; World Bank: Washington, DC, USA; FAO: Rome, Italy; IFAD: Rome, Italy, 2015.

116. FAO. Gender and Land Rights Database. Available online: http://www.fao.org/gender-landrights-database/ country-profiles/countries-list/en/ (accessed on 1 April 2020).

117. United Nations. Global Indicator Framework for the Sustainable Development Goals and Targets of the 2030 Agenda for Sustainable Development; United Nations: New York, NY, USA, 2019.

118. FAO. Developing Gender-Equitable Legal Frameworks for Land Tenure-A Legal Assessment Tool; FAO: Rome, Italy, 2016.

119. Global Land Tool Network; UN Habitat. Gendering Land Tools-Achieving Secure Tenure for Women and Men; Global Land Tool Network (GLTN) and United Nations Human Settlements Programme (UN-Habitat): Nairobi, Kenya, 2008.

120. Global Land Tool Network; UN Habitat. Global Land Tool Network Gender Strategy (2019-2030)—Towards Securing Women's and Girls' Land and Property Rights; Global Land Tool Network (GLTN) and United Nations Human Settlements Programme (UN-Habitat): Nairobi, Kenya, 2019.

121. The Global Initiative for Economic, Social and Cultural Rights. Using CEDAW to Secure Women's Land and Property Rights: A Practical Guide; GI-ESCR: Duluth, MN, USA, 2014. 
122. Akrofi-Atitianti, F.; Ifejika Speranza, C.; Bockel, L.; Asare, R. Assessing Climate Smart Agriculture and Its Determinants of Practice in Ghana: A Case of the Cocoa Production System. Land 2018, 7, 30. [CrossRef]

123. Manda, J.; Alene, A.D.; Gardebroek, C.; Kassie, M.; Tembo, G. Adoption and Impacts of Sustainable Agricultural Practices on Maize Yields and Incomes: Evidence from Rural Zambia. J. Agric. Econ. 2016, 67, 130-153. [CrossRef]

124. Fenske, J. Land tenure and investment incentives: Evidence from West Africa. J. Devel. Econ. 2011, 95, 137-156. [CrossRef]

125. Christoplos, I. Mobilizing the Potential of Rural and Agricultural Extension; FAO: Rome, Italy, 2010.

126. Poulton, C.; Dorward, A.; Kydd, J. The Future of Small Farms: New Directions for Services, Institutions, and Intermediation. World Dev. 2010, 38, 1413-1428. [CrossRef]

127. IFAD; WFP. Potential for Scale and Sustainability in Weather Index Insurance for Agriculture and Rural Livelihoods; WFP: Rome, Italy, 2010.

128. Putzel, J. Land Reforms in Asia: Lessons from the Past for the 21st Century; LSE Development Studies Institute: London, UK, 2000.

129. De Janvry, A.; Sadoulet, E. A study in resistance to institutional change: The lost game of Latin American land reform. World Dev. 1989, 17, 1397-1407. [CrossRef]

130. Abdulai, A.; Huffman, W. The Adoption and Impact of Soil and Water Conservation Technology: An Endogenous Switching Regression Application. Land Econ. 2014, 90, 26-43. [CrossRef]

131. Le Dang, H.; Li, E.; Nuberg, I.; Bruwer, J. Factors influencing the adaptation of farmers in response to climate change: A review. Clim. Dev. 2019, 11, 765-774. [CrossRef]

132. Mwungu, C.M.; Mwongera, C.; Shikuku, K.M.; Acosta, M.; Läderach, P. Determinants of Adoption of Climate-Smart Agriculture Technologies at Farm Plot Level: An Assessment from Southern Tanzania. In Handbook of Climate Change Resilience; Springer: Berlin/Heidelberg, Germany, 2018; pp. 1-15. [CrossRef]

133. Porrini, D.; Fusco, G.; Miglietta, P.P. Post-Adversities Recovery and Profitability: The Case of Italian Farmers. Int. J. Environ. Res. Public Health 2019, 16, 3189. [CrossRef]

134. Amare, M.; Asfaw, S.; Shiferaw, B. Welfare impacts of maize-pigeonpea intensification in Tanzania. Agric. Econ. 2012, 43, 27-43. [CrossRef]

135. FAO. Climate Smart Agriculture: Building Resilience to Climate Change; FAO: Rome, Italy, 2018.

136. Murage, A.W.; Midega, C.A.O.; Pittchar, J.O.; Pickett, J.A.; Khan, Z.R. Determinants of adoption of climate-smart push-pull technology for enhanced food security through integrated pest management in eastern Africa. Food Secur. 2015, 7, 709-724. [CrossRef]

137. Clark, J. The Effectiveness and Sustainability of the Input Supplier Model.; IDS: Brighton, UK, 2012.

138. World Bank. World Development Report 2008: Agriculture for Development; World Bank: Washington, DC, USA, 2007.

139. Lipton, M. Land reform as commenced business: The evidence against stopping. World Dev. 1993, 21, 641-657. [CrossRef]

140. World Bank. World Development Report 1994: Infrastructure for Development; Oxford University Press: New York, NY, USA, 1994.

141. Ali, A.; Erenstein, O. Assessing farmer use of climate change adaptation practices and impacts on food security and poverty in Pakistan. Clim. Risk Manag. 2017, 16, 183-194. [CrossRef]

142. Bryan, E.; Ringler, C.; Okoba, B.; Roncoli, C.; Silvestri, S.; Herrero, M. Adapting agriculture to climate change in Kenya: Household strategies and determinants. J. Environ. Manag. 2013, 114, 26-35. [CrossRef]

143. Birner, R.; Davis, K.; Pender, J.; Nkonya, E.; Anandajayasekeram, P.; Ekboir, J.; Mbabu, A.; Spielman, D.J.; Horna, D.; Benin, S.; et al. From Best Practice to Best Fit: A Framework for Designing and Analyzing Pluralistic Agricultural Advisory Services Worldwide. J. Agric. Educ. Ext. 2009, 15, 341-355. [CrossRef]

144. Anderson, J.R. Agricultural Advisory Services; World Bank: Washington, DC, USA, 2007.

145. Anderson, J.R.; Feder, G.; Ganguly, S. The Rise and Fall of Training and Visit Extension: An. Asian Mini-drama with an African Epilogue; World Bank: Washington, DC, USA, 2006.

146. FAO; World Bank. Agricultural Knowledge and Information Systems for Rural Development (AKIS/RD). Strategic Vision and Guiding Principles; FAO: Rome, Italy, 2000.

147. Rivera, W.M.; Alex, G.; Hanson, J.; Birner, R. Enabling agriculture: The evolution and promise of agricultural knowledge framework. In Proceedings of the Association for International Agricultural and Extension Education, Clearwater Beach, FL, USA, 19-22 May 2013. 
148. World Bank. Agricultural Innovation Systems: An. Investment Sourcebook; World Bank: Washington, DC, USA, 2012.

149. Alex, G.; Zijp, W.; Byerlee, D. Rural Extension and Advisory Services-New Directions; World Bank: Washington, DC, USA, 2002.

150. World Bank; IFPRI. Gender and Governance in Rural Services: Insights from India, Ghana, and Ethiopia; World Bank: Washington, DC, USA, 2010. [CrossRef]

151. Anderson, J.R.; Feder, G. Rural Extension Services; World Bank: Washington, DC, USA, 2003.

152. Clarkson, G.; Dorward, P.; Osbahr, H.; Torgbor, F.; Kankam-Boadu, I. An investigation of the effects of PICSA on smallholder farmers' decisionmaking and livelihoods when implemented at large scale-The case of Northern Ghana. Clim. Serv. 2019, 14,1-14. [CrossRef]

153. Gido, E.O.; Sibiko, K.W.; Ayuya, O.I.; Mwangi, J.K. Demand for Agricultural Extension Services Among Small-Scale Maize Farmers: Micro-Level Evidence from Kenya. J. Agric. Educ. Ext. 2015, 21, 177-192. [CrossRef]

154. Swanson, B.E. Global Review of Good Agricultural Extension and Advisory Service Practices; FAO: Rome, Italy, 2008.

155. Swanson, B.E.; Samy, M.M. Introduction to Decentralization of Agricultural Extension Systems: Key Elements for Success. In Decentralized Systems: Case Studies of International Initiatives., Rivera, W., Alex, G., Eds.; World Bank: Washington, DC, USA, 2004; Volume 1, pp. 1-5.

156. FAO. Climate-Smart Agriculture Training Manual—A Reference Manual for Agricultural Extension Agents; FAO: Rome, Italy, 2018.

157. FAO. Upscaling Climate Smart Agriculture_Lessons for Extension and Advisory Services; FAO: Rome, Italy, 2018.

158. FAO; Ministry of Agriculture Livestock and Fisheries. Climate-Smart Agriculture Training Manual for Agricultural Extension Agents in Kenya; FAO: Rome, Italy, 2018.

159. Ngara, T. Climate-Smart Agriculture Manual for Agriculture Education in Zimbabwe; Ngara, T., Ed.; Climate Technology Centre \& Network: Copenhagen, Demark, 2017.

160. Sala, S.; Rossi, F.; David, S. (Eds.) Supporting Agricultural Extension Towards Climate-Smart Agriculture. An Overview of Existing Tools; Global Alliance for Climate-Smart Agriculture (GACSA): Rome, Italy, 2016.

161. Sulaiman, R.V. Enabling Advisory Services for Climate-Smart Agriculture. Key Elements to Foster Farmers' Adoption of CSA Practices; Global Alliance for Climate-Smart Agriculture (GACSA): Rome, Italy, 2017.

162. Asfaw, S.; Shiferaw, B.; Simtowe, F.; Lipper, L. Impact of modern agricultural technologies on smallholder welfare: Evidence from Tanzania and Ethiopia. Food Policy 2012, 37, 283-295. [CrossRef]

163. Khonje, M.; Manda, J.; Alene, A.D.; Kassie, M. Analysis of Adoption and Impacts of Improved Maize Varieties in Eastern Zambia. World Dev. 2015, 66, 695-706. [CrossRef]

164. Makate, C.; Makate, M.; Mutenje, M.; Mango, N.; Siziba, S. Synergistic impacts of agricultural credit and extension on adoption of climate-smart agricultural technologies in southern Africa. Environ. Dev. 2019, 32. [CrossRef]

165. Beyene, A.D.; Mekonnen, A.; Kassie, M.; Di Falco, S.; Bezabih, M. Determinants of Adoption and Impacts of Sustainable Land Management and Climate Smart Agricultural Practices (SLM-CSA): Panel Data Evidence from the Ethiopian Highlands. Environ. Dev. Initiat. Discuss. Pap. Ser. 2017, 10, 1-30.

166. Dorward, P.; Clarkson, G.; Stern, R. Participatory Integrated Climate Services for Agriculture (PICSA): Field Manual; Walker Institute, University of Reading: Reading, UK, 2015.

167. Mulwa, C.; Marenya, P.; Rahut, D.B.; Kassie, M. Response to climate risks among smallholder farmers in Malawi: A multivariate probit assessment of the role of information, household demographics, and farm characteristics. Clim. Risk Manag. 2017, 16, 208-221. [CrossRef]

168. Toma, P.; Miglietta, P.P.; Zurlini, G.; Valente, D.; Petrosillo, I. A non-parametric bootstrap-data envelopment analysis approach for environmental policy planning and management of agricultural efficiency in EU countries. Ecol. Indic. 2017, 83, 132-143. [CrossRef]

169. FAO. Climate-Smart Agriculture and the Sustainable Development Goals: Mapping Interlinkages, Synergies and Trade-Offs and Guidelines for Integrated Implementation; FAO: Rome, Italy, 2019.

Publisher's Note: MDPI stays neutral with regard to jurisdictional claims in published maps and institutional affiliations. 